\section{'Florida 202' and 'Everglades': Two New Butterhead Lettuce Cultivars Adapted to Florida}

\author{
V.L. Guzman ${ }^{1}$, R.T. Nagata ${ }^{2}$, L.E. Datnoff ${ }^{3}$, and R.N. Raid ${ }^{4}$ \\ University of Florida, Institute of Food and Agricultural Sciences, \\ Everglades Research and Education Center, P.0. Box 8003, Belle \\ Glade, FL 33430-8003
}

Additional index words. bolting, Bremia lactucae, corky root, disease resistance, downy mildew, Lactuca sativa, lettuce mosaic virus, organic soil, pedigree breeding, tipburn, vegetable breeding, Rhizomonas suberifaciens

Lettuce (Lactuca sativa L.) production in Florida is primarily on organic soils found in the southern and central portions of the state. The unique environmental conditions of climate and soil mandate the development and/or use of adapted cultivars. This subtropical climate is also conducive to the development of many diseases and can induce a variety of environmental stresses. When the lettuce breeding program started in Florida during the early 1970s, lettuce mosaic virus (LMV) was one of the most serious diseases limiting lettuce production. Initial efforts were to develop LMV-resistant lettuce cultivars adapted to Florida conditions. During the mid-1970s, corky root (CR), caused by Rhizomonas suberifaciens van Bruggen et al. (Datnoff and Nagata, 1990; van Bruggen et al., 1990), became the most devastating disease of lettuce in Florida. Breeding efforts were then redirected to include CR resistance. The two new butterhead cultivars described herein, 'Florida 202' and 'Everglades', are adapted to Florida conditions and both have resistance to LMV. The former is resistant to $\mathrm{CR}$, while the latter is tolerant to the disease. 'Everglades' is also resistant to lettuce downy mildew (Bremia lactucae Regel) (Datnoff et al., 1990).

\section{Origin}

'Florida 202' was derived from a 'Montello' $\times$ 'Brazil-48' cross made in 1980, followed by six generations of pedigree selection and two mass seed increases. This cultivar

Received for publication 2 Aug. 1991. Accepted for publication 23 Jan. 1992. Univ. of Florida Agricultural Experiment Station. Journal Series no. R-00891. The cost of publishing this paper was defrayed in part by the payment of page charges. Under postal regulations, this paper therefore must be hereby marked advertisement solely to indicate this fact.

'Professor Emeritus of Horticulture.

2Assistant Professor of Horticulture, to whom reprint requests should be addressed.

${ }^{3}$ Assistant Professor of Plant Pathology.

${ }^{4}$ Assistant Professor of Plant Pathology. was tested as breeding lines 70202 and 80091.

The origin of 'Everglades' began in 1973 when line $G$ (Great Lakes' $\times$ 'Fulton', $F_{2}$ ), from G. Raleigh's program at Cornell Univ., was crossed to 'Gallega' (Fig. 1). In 1974, a single $\mathrm{F}_{2}$ plant selection was crossed to 'Dark Green Boston'. A single F plant was then crossed to 'Troc' in 1975. 'Everglades' resulted from eight generations of pedigree selection followed by two mass seed increases. This line was tested as breeding line 70291.

\section{Description}

'Florida 202' is an attractive butterhead lettuce with medium-green foliage, maturing $\approx 55$ days after sowing. Seeds are white. At maturity, leaves cup inward and overlap to form a well-developed medium to large
Fig. 1. Pedigree of 'Everglades' butterhead lettuce. spherical head with an average weight of 261 $\mathrm{g}$, based on five tests (Table 1). The leaves are slightly blistered, but this should not cause problems with soil accumulation. The interior of the head is buttery-yellow with a small basal stem. The basal end of the head is light green to white, and the midribs are normally smooth and seldom ribby. 'Florida 202' is highly resistant to CR and LMV. It is also resistant to bolting and tipbum. However, it is susceptible to a downy mildew isolate that is similar to California Pathotype IV (Schettini et al., 1991). This cultivar is recommended for fall and spring harvest in southern Florida due to the absence of downy mildew resistance.

'Everglades' is a medium-green butterhead lettuce that is suitable for planting from mid-October to February in southern Florida. Leaves-extend outward from the basal stem without folding over to form a "normal" head with inward cupping leaves as found in 'Florida 202'. Despite the abnormal open rosette head configuration, 'Everglades' forms a large, high-quality head averaging $312 \mathrm{~g}$, based on two trials (Table 1), and is capable of producing heads of $450 \mathrm{~g}$ or more. 'Everglades' has a harvest maturity range of 3 to 5 days in winter. Heads at maturity are attractive, with a smooth basal end that is seldom ribby. Internal leaves are a golden yellow at harvest maturity. Tipburn in 'Everglades' is rare and, therefore, it is considered highly tolerant. It is completely resistant to the downy mildew isolate that resembles the California Pathotype IV, mating type B (sporulation is absent against differential Dm resistant genes 4, 10, and 16)

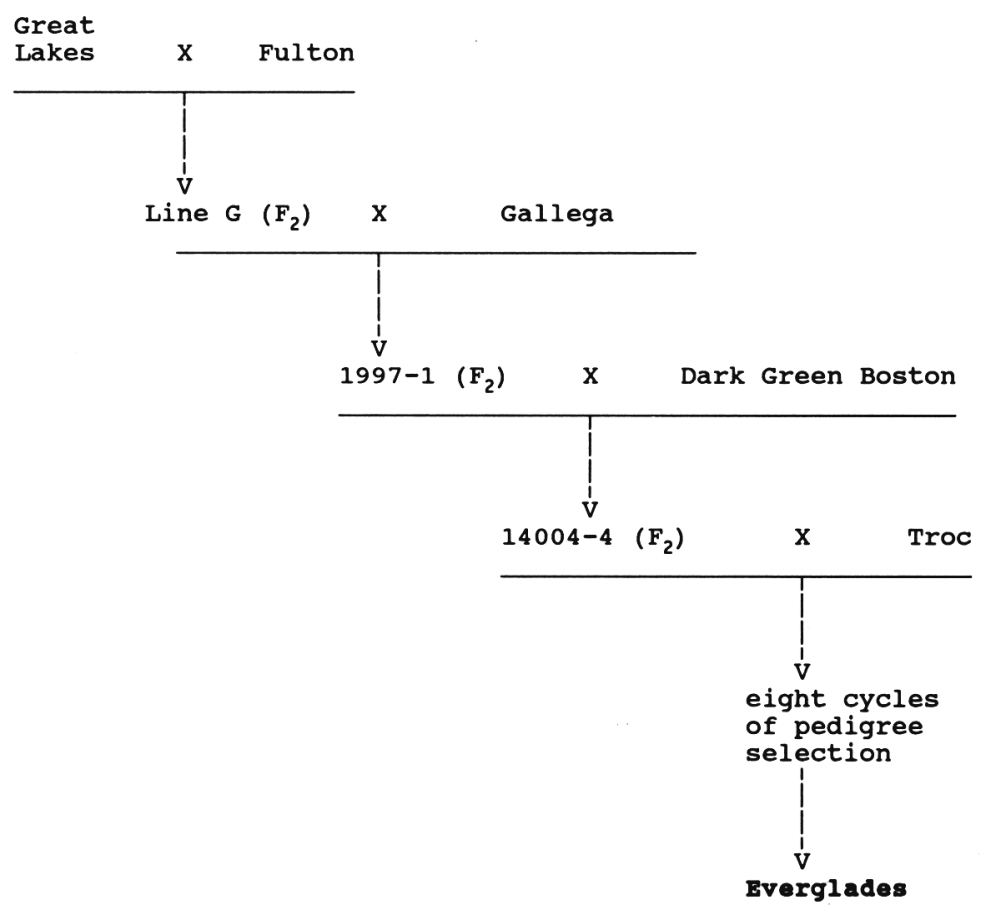


Table 1. Average head weights for 'Florida 202' and 'Everglades' grown on the organic soils of southern Florida.

\begin{tabular}{|c|c|c|c|c|}
\hline Location & Plant date & Harvest date & Cultivar & $\begin{array}{l}\text { Head wt } \\
(\mathrm{g})^{2}\end{array}$ \\
\hline Belle Glade & 8 Sept. 1989 & 3 Nov. 1989 & $\begin{array}{l}\text { Florida Buttercrisp } \\
\text { Florida } 202\end{array}$ & $\begin{array}{l}219 a \\
206 a\end{array}$ \\
\hline Belle Glade & 3 Oct. 1989 & 27 Nov. 1989 & $\begin{array}{l}\text { Dark Green Boston } \\
\text { Florida Buttercrisp } \\
\text { Florida } 202\end{array}$ & $\begin{array}{l}297 \mathrm{ab} \\
286 \mathrm{abc} \\
260 \mathrm{bc}\end{array}$ \\
\hline Lake Harbor & 13 Oct. 1989 & 1 Dec. 1989 & $\begin{array}{l}\text { Dark Green Boston } \\
\text { Florida Buttercrisp } \\
\text { Florida } 202\end{array}$ & $\begin{array}{l}299 a \\
276 b c \\
266 c\end{array}$ \\
\hline Lake Harbor & 9 Jan. 1990 & 7 Mar. 1990 & $\begin{array}{l}\text { Florida Buttercrisp } \\
\text { Everglades } \\
\text { Florida } 202\end{array}$ & $\begin{array}{l}332 \mathrm{a} \\
288 \mathrm{~b} \\
286 \mathrm{~b}\end{array}$ \\
\hline Belle Glade & 11 Jan. 1990 & 3-13 Mar. 1990 & $\begin{array}{l}\text { Everglades } \\
\text { Florida } 202 \\
\text { Dark Green Boston }\end{array}$ & $\begin{array}{l}337 \mathrm{a} \\
285 \mathrm{~b} \\
262 \mathrm{~b}\end{array}$ \\
\hline
\end{tabular}

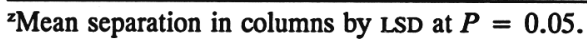

(Datnoff et al., 1990; Schettini et al., 1991). It is also resistant to LMV and spring yellows virus (Falk and Guzman, 1981). However, it is moderately susceptible to CR. Seeds are dark brown and have a thermotolerant character that allows $90 \%$ or better germination of nonprimed seeds at a constant $35 \mathrm{C}$ within $72 \mathrm{~h}$. This characteristic makes it well suited for fall planting, when soil tempera- ers, Inc., P.O. Box 308, Greenwood, FL 32443. Seed stock was produced in California and was indexed at 0/30,000 infected seeds for LMV.

\section{Literature Cited}

Datnoff, L.E. and R.T. Nagata. 1990. Isolation of Rhizomonas suberifaciens in Florida. Plant Dis. 74:394.

Datnoff, L.E., R.T. Nagata, R.N. Raid, T.M. Schettini, and R.W. Michelmore. 1990. Field evaluation of crisphead and butterhead lettuce for downy mildew resistance and characterization of virulence phenotype. Proc. Fla. State Hort. Soc. 103:140-142.

Falk, B.W. and V.L. Gunman. 1981. A virus as the causal agent of spring yellows of lettuce and escarole. Proc. Fla. State Hort. Soc. 94:149152.

tures can exceed $32 \mathrm{C}$ and seed thermodormancy can be a major problem. 'Everglades' is susceptible to bolting when exposed to high temperatures for an extended time.

\section{Seed availability}

Inquiries on seed availability should be directed to Florida Foundation Seed Produc-
Schettini, T.M., E.J. Legg, and R.W. Michelmore. 1991. Insensitivity to metalaxyl in California populations of Bremia lactucae and resistance of California lettuce cultivars to downy mildew. Phytopathology 81:64-70.

van Bruggen, A.H.C., K.N. Jochimsen, and P.R. Brown. 1990. Rhizomonas suberifaciens, gen. nov., sp. nov., the causal agent of corky root of lettuce. Intl. J. Syst. Bacteriol. 40:175-188. 